\title{
FUNCTIONAL PROPERTIES OF LEUCAENA LEUCOCEPHALA PROTEIN CONCENTRATES RESULTED SEPARATION OF ULTRAFILTRATION MEMBRANE
}

\author{
Dedin Finatsiyatull Rosida ${ }^{*}$, Nur Hapsari, Taufik Hidayah \\ Departement of Food Technology \\ University of Pembangunan Nasional "Veteran" Jawa Timur, Surabaya, Indonesia \\ Email: $\left.{ }^{*}\right)$ dedin.tp@upnjatim.ac.id
}

\begin{abstract}
Protein is a polypeptide, which is composed of a series of amino acids, with a relatively very large molecular weight, which ranges from 8,000 to $10,000 \mathrm{Da}$. Separation of protein can be done by chemical, enzymatic or using an ultrafiltration membrane. Applications of protein concentrates product depends on its functional properties such as water absorption, oil absorption capacity and power emulsions, and foaming power which will affect the quality of product. Food product that use protein concentrates in the form of sausages, meatballs, bakery and beverages. Techniques of membrane separation are generally based on particle size and molecular weight of the thrust in the form of pressure differences, and different electric field concentration. This study aims to determine the role of membrane ultrafiltration to separate proteins and produce the characteristic functional properties. This study used two main factors, ultrafiltration membrane pressure (2.33 atm, $3.66 \mathrm{~atm})$ and the separation time (15 minutes, 30 minutes, 45 minutes). The resulted showed leucaena seed protein concentrates obtained from the best treatment of $3.66 \mathrm{~atm}$ pressure and separation time 45 minutes. Concentrates of leucaena seed had the functional properties of the water absorption capacity of $3.3 \mathrm{~g}$ water/g of solid, oil absorption capacity of $1.43 \mathrm{~g}$ of oil/g solid, Bulk density of $0.55 \mathrm{~g} / \mathrm{ml}$, power emulsion $51.11 \%$ and power foam $9.8 \%$.
\end{abstract}

Keywords: Protein, leucaena, ultrafiltration membrane, functional properties

\section{INTRODUCTION}

In several processing industries, separation of different components from a mixture is an important unit operation. Sometimes the separated component is an important product. There is a variety of technologies available for use in separations, each operating based on physical and chemical properties of the mixture. One of the fundamental separation processes that brought about a major change in processing of protein concentrate-product streams is membrane separation technology. Membrane separations work on the basis of differences in size and shape of the molecules. Today dairy industry accounts for major share in the total membrane area installed (Marella et al., 2013).

Leucaena leucocephala has been used by the community as shade trees, erosion control, firewood and fodder. Leucaena seed utilization is very limited whereas seeds contain high protein (30-40\%) (Suprihatin, 2009). Rahayu et al., (2005) shows that the use of leucaena on soysauce containes protein $20.86 \%$. The use of protein concentrates more desirable than flour bean because protein concentrates have functional properties that are large and relatively free of toxic factors and carbohydrates that can not be digested (Neto et al., 2001 cited in Adebowale and Lawal, 2003). The previous research has produced leucaena seed protein concentrate that had the protein $56.30 \%$ (db) on the concentration of enzyme treatment of sheep rumen fluid $(10 \mathrm{~mL} / 100 \mathrm{~g})$ and incubation time of $48 \mathrm{~h}$ (Dedin F.Rosida et al., 2015). Applications of this protein concentrates depend on its functional properties of proteins such as water absorption, oil absorption capacity, power emulsions, and foaming. The functional properties are characterized by the physicochemical characteristics of food proteins that can determine behavior in food during processing, storage, and consumption.

The production of protein concentrates can be obtained using membrane fractionation process triggered by the pressure difference between the feed stream and the product stream (permeate). In this study, protein concentrates was made from separation method using ultrafiltration membranes. The principle of the use of ultrafiltration membranes are fractionated by molecular weight ultrafiltration membrane pore qualify. Factors that affect the membrane include molecular size, molecular shape, membrane materials, the characteristics of the solution, and operational parameters such as pressure, temperature, concentration, $\mathrm{pH}$, ionic strength, polarization (Eden, 2012). 
Membrane technology has several advantages compared to other processes, such as: Separation can be carried out continuously, energy consumption is generally relatively low, membranes process can easily be combined with other separation processes (hybrid processing), separation can be performed in a condition that is easily created, easy to scale-up, no need for additional material and the membrane material is so easily used

Reverse Osmosis (RO), Nanofiltration (NF), Ultrafiltration (UF) and Microfiltration (MF) are four commonly used membrane separation process. These processes have evolved from consistent research and development in the area of new membrane material development as well as applications (Marella et al 2009).

Chemical properties of the membrane which is important in membrane separation processes, among others: (1) the nature of the hydrophilic or hydrophobic; (2) charge on the ion; (3) resistance to high temperatures and certain chemical substances; and (4) the appeal against the particles in the feed (Osada and Nagawa, 1992). Membrane processes are grouped by size separation and applications that can be applied (Gutman, 1987).

Membrane microfiltration and ultrafiltration have been applied in the food industries for the purpose of concentrating, purifying biopolymer to a solution of macromolecules such as proteins and polysaccharides. The industrial thermal processing of foods may have a severe impact on the sensorial and nutritional properties of the final product. Membrane technologies have been extensively studied as alternative processes. Forward osmosis (FO) is a promising membrane technology to be used in food industries. The only driving force of the process is the osmotic pressure difference between the two solutions that flow in counter-current mode on opposite sides of a permeable membrane. Thus, the main advantages of FO, compared to both thermal and conventional membrane processing, include low hydraulic pressure, low treatment temperature, low fouling tendency, high solids content processing capability and easy to scaleup (Sant'Anna et al., 2012). The separation membrane performance is influenced by the characteristics of the membrane used. Assessment of the characteristics of such a membrane that covers the structure and pore size and other physical properties of the chemical. The main parameters used in the assessment of the performance of the membrane filtration is the flux and rejection (Osada and Nakagawa, 1992). This study aims to determine the role of membrane ultrafiltration to separate proteins and produce the specific characteristic functional properties

\section{METHODOLOGY}

Raw materials was Leucaena leucocephala seeds. The study began with soaking seeds for 24 hours, then stripping the skin and let dried. The next steps were grinding and sieving to 100 mesh.

Leucaena flour was added $0.01 \mathrm{~N} \mathrm{HCl} 100 \mathrm{~mL}$ to stirr for 1 hour and neutralized with $0.01 \mathrm{~N} \mathrm{NaOH}$ solution of $100 \mathrm{~mL}$. The starting of the protein separation used ultrafiltration membranes with a pore size of the membrane $0.45 \mu \mathrm{m}$. The pressure levels used during the separation were: $2,333 \mathrm{~atm}$ and A2: $3.667 \mathrm{~atm}$, while the fractionation time were: 15 minutes, 30 minutes and 45 minutes. The last step was washing with $200 \mathrm{ml}$ of distilled water and dried. The protein concentrate parameters was observed to include: Protein yield, Bulk density (Okezie and Bello, 1988), the absorption of oil (Soluski and Fleming, 1977), permeability (Lin et al., 1974), power foam (Widowati et al., 1998), capacity and emulsion stability (modification Franzen and Kinsella, 1979).

Analysis of Water Absorption was done by taking a sample of $1 \mathrm{~g}$ and $10 \mathrm{~mL}$ of distilled water for 2 minutes vortex, chilled for 1 hour at room temperature and then centrifuged at $3000 \mathrm{rpm}$ for 25 minutes. Filtrate volume was measured. Water absorption (water $\mathrm{mL} / \mathrm{g}$ sample) was calculated by the following equation: $(10 \mathrm{~mL}$ - vol filtrate $\mathrm{mL}) / \mathrm{W}$ sample (g) (Lin et al, 1974)

Analysis of Oil Absorption was done by taking a sample of $0.5 \mathrm{~g}$ plus $3 \mathrm{~mL}$ of soybean oil vortex for 2 minutes and then allowed to stand at room temperature. The mixture was centrifuged at $3000 \mathrm{rpm}$ for 25 minutes. Supernatant was poured into $10 \mathrm{~mL}$ measuring cup and free oil was observed. Volume oil absorption (oil $\mathrm{mL} / \mathrm{g}$ sample) measurements performed in two repetitions with the following equation: $(3 \mathrm{~mL}$ of oil - filtrate)/W sample (g) (Soluski and Fleming, 1977) 


\section{RESULT AND DISCUSSION}

\section{Protein Value}

Nutrient content in leucaena with skin is protein $19.75 \%$, fat $5.58 \%$, moisture $14.31 \%$ and ash $5.66 \%$. The results of the analysis flour leucaena seed without seed skin is obtained moisture $12.26 \%$, ash 6.73 , fat $3.19 \%$ and protein $55.38 \%$ (Dedin F.Rosida et al 2012). It is suspected that leucaena was processed into flour without involving the skin, where the skin contains cellulose and flouring processes can reduce the moisture content so that the protein concentration in leucaena seed flour was higher. Leucaena seed flour without skin contains approximately $50 \%$ protein (Budianto et al., 1987)

The average levels of protein concentrates in leucaena seed with pressure treatment were between $47.79 \%-49.42 \%$ (Table 1), the greater the pressure inside the membrane, larger the protein content. This occured because the fluid passing through the membrane more filtered with increased pressure. The size of the protein ranged from 0.03 to $0.3 \mu \mathrm{m}$, while the pore size microfiltration membrane ranged from 0.1 to $1.0 \mu \mathrm{m}$. so leucaena seed proteins can pass through the membrane pore size of $0.45 \mu \mathrm{m}$.

Table-1. Protein value of Leucaena protein concentrate

\begin{tabular}{cl}
\hline Treatment & Protein value (\%) \\
\hline Pressure (atm) & \\
2.33 & $47,79 \pm 2,266^{\mathrm{a}}$ \\
3.66 & $49,42 \pm 2,031^{\mathrm{a}}$ \\
Time (minutes) & \\
15 & $47,77 \pm 2,732^{\mathrm{a}}$ \\
30 & $48,76 \pm 1,422^{\mathrm{a}}$ \\
45 & $49,28 \pm 2,516^{\mathrm{a}}$ \\
\hline
\end{tabular}

The average levels of leucaena seed protein concentrates with a separation time of 15 minutes was $47.77 \%, 48.76 \%$ at 30 minutes, $49.28 \%$ at 45 minutes (Table 1). Time is one thing that plays a role in improving the protein content outcomes. The longer time given the higher ability of material to go through the membrane by the pressure exerted, there are deficiencies which may be generated from a given length of time that a build up of material in the pores of the membrane making the material can not be passed through membrane. Membrane performance can be decreased by the presence of fouling and polarization concentration. Polarization concentration and fouling can limit the membrane separation process since both cause a decrease in the permeate flux (Wenten, 1999).

Membrane serves to separate material based on the size and shape of the molecule to hold the components of the feed which has a larger size than the pores of the membrane and to skip parts that have a smaller size. Using membrane filtration in addition to function as a means of separation also serves as a means of concentration and purification of a solution passed on the membrane.

According to the desired separation process, the membrane can be divided into microfiltration, ultrafiltration and reverse osmosis with a sequence of increasingly smaller pore size. Among the three types of membrane, ultrafiltration has the most extensive applications in industries such as fermentation, food and beverage industry, semi-conductors and others (Osada and Nakagawa, 1992).

\section{Functional Properties}

The water absorption of leucaena concentrates with pressure was 3.12 - 3,22 g water/g solid (Table 2). The water absorption of leucaena concentrates with a time separation was $3.03-3.28 \mathrm{~g}$ water/g solid. Water absorption or water holding capacity is the ability of proteins to bind water during force use, pressure, centrifugation and heating (Zayas, 1997). The higher pressure showed an increase in the protein content of leucaena concentrates that affected the increased absorption of water. 
Table -2. Functional Properties of Leucaena protein concentrate

\begin{tabular}{|c|c|c|c|c|c|}
\hline Treatment & $\begin{array}{c}\text { Water } \\
\text { absorption } \\
\text { (g air/g } \\
\text { solid ) }\end{array}$ & $\begin{array}{c}\text { Oil } \\
\text { absorption } \\
\text { (g oil/g solid ) }\end{array}$ & $\begin{array}{c}\text { Bulk density } \\
(\%)\end{array}$ & $\begin{array}{l}\text { ver emulsion } \\
(\%)\end{array}$ & $\begin{array}{c}\text { Power Foam } \\
(\%)\end{array}$ \\
\hline \multicolumn{6}{|c|}{ Pressure (atm) } \\
\hline 2.33 & $3,12 \pm 0,249^{a}$ & $1,2 \pm 0,186^{\mathrm{a}}$ & $0,58 \pm 0,013^{\mathrm{a}}$ & $47,67 \pm 2,422^{\mathrm{a}}$ & $7,55 \pm 1,648^{a}$ \\
\hline 3.66 & $3,22 \pm 0,192^{\mathrm{a}}$ & $1,3 \pm 0,228^{\mathrm{a}}$ & $0,56 \pm 0,015^{\mathrm{a}}$ & $50,20 \pm 2,465^{\mathrm{a}}$ & $8,61 \pm 1,746^{\mathrm{a}}$ \\
\hline \multicolumn{6}{|c|}{ Time (minutes) } \\
\hline 15 & $3,03 \pm 0,234^{\mathrm{a}}$ & $1,25 \pm 0,238^{\mathrm{a}}$ & $0,58 \pm 0,017^{\mathrm{a}}$ & $47,84 \pm 3,037^{\mathrm{a}}$ & $7,0 \pm 1,789^{a}$ \\
\hline 30 & $3,2 \pm 0,141^{\mathrm{a}}$ & $1,23 \pm 0,115^{\mathrm{a}}$ & $0,58 \pm 0,012^{\mathrm{a}}$ & $48,78 \pm 1,990^{\mathrm{a}}$ & $8,1 \pm 1,033^{\mathrm{a}}$ \\
\hline 45 & $3,28 \pm 0,232^{\mathrm{a}}$ & $1,38 \pm 0,294^{\mathrm{a}}$ & $0,56 \pm 0,015^{\mathrm{a}}$ & $50,17 \pm 3,208^{\mathrm{a}}$ & $9,0 \pm 1,828^{\mathrm{a}}$ \\
\hline
\end{tabular}

The water absorption is also affected by the concentration of the protein and the presence of other components such as hydrophilic polysaccharides, fats, salt, and is also influenced by the length of the heating and storage conditions. The higher the concentration of protein in a food, the water absorption capacity is increasing (Zayas, 1997 in Gunawan, 2009).

The oil absorption of leucaena concentrates with pressure was 1.2 - $1.3 \mathrm{~g}$ water/g solid (Table 3 ). The oil absorption of leucaena concentrates with a time separation was $1.25-1.38 \mathrm{~g}$ oil $/ \mathrm{g}$ solid. Characteristics of food products involves many interactions between proteins and fats, such as the formation of emulsions, the emulsification of fat in meat, absorption flavor and texture of the dough. Kinsella (1979) describe the mechanism of oil absorption as a physical phenomenon of trapped oil. The absorption of oil is determined by the binding of fat by non polar groups on the protein (Kinsella 1979; Sathe et al. 1982).

In a food product in the form of powder, fat binding is affected by particle size. Protein in the form of powder with low density and small particle size can absorb and trap more oil than high density protein (Zayas, 1997). Fat binding ability of the protein is essential for the application of protein as meat replacement and extension with respect to mouthfeel and flavor retention involving the holding capacity of fat in the product. The value of oil absorption capacity of leucaena protein concentrates compare to oil absorbency of commercial soy protein concentrates (ISOPRO) was $1.1704 \mathrm{~g}$ oil / g solid (Lin et al., 1974).

The bulk density of leucaena concentrates with pressure treatment was $0.58 \%-0.56 \%$ and treated- separation time was $0.58 \%-0.56 \%$. Bulk density is the mass of particles that occupy a certain volume unit (Wirakartakusumah, et al., 1992). Bulk density stated the brevity of a material in occupied volume. The greater the bulk density, the more compact the material because it can occupy the same volume in a greater weight. Bulk density is also the ratio between the weight of the volume of material that is expressed in $\mathrm{g} / \mathrm{mL}$. Peleg and Bagley (1983) states that the Bulk density depends on several factors, namely the attraction between the particles, particle size and surface area of the particles touch. Bulk density of protein concentrates are influenced by increased cohesiveness of particles and moisture. The statement was reinforced by the opinions Wirakartakusumah et al., (1992), which states that in general, water absorption associated with increased cohesion, mainly caused by the liquid bridges between the particles. Therefore, food powder which is hygroscopic at high water levels caused a decrease in bulk density.

Bulk density is influenced by the particle size, the properties of materials, material composition, and may also be influenced by the degradation of the molecules in the material due to processing. So the bulk density values can be caused by the degradation of starch molecules, proteins, fats, and others when treated early ripening so that the molecules occupy a smaller space (Winata 2001).

The emulsion power of leucaena concentrates with pressure treatment was $47.67 \%-50.20 \%$. The mean power emulsion of leucaena concentrates with a treatment time of separation was $47.84 \%-50.17 \%$. The emulsion is defined as a mixture of two or more liquids that do not dissolve each other, which is a liquid dispersed in the form of globules or small grains in other liquids. Dispersed liquid called discontinuous phase while dispersing a fluid which is called the continuous phase (Fardiaz, et al., 1992). Protein 
emulsion properties is the ability of a protein to form an emulsion. Protein emulsion activity is the ability of a protein in the formation of the emulsion and its stabilize (Zayas, 1997). The protein solubility, surface hydrophobicity and flexibility emulsion protein molecules influence the properties of globular proteins. Therefore, the ability of the membrane to produce optimal protein concentrates power is associated with an emulsion of a protein concentrates (Nakai et al. 1980),

The higher the solubility of proteins, the higher the ability to form a layer that envelops oil emulsion doplet so that the activity increases (Suwarno et al., 2003). Emulsion formation by proteins is influenced by internal and external factors. Internal factors include $\mathrm{pH}$, ionic strength, temperature, molecular weight surfactants, and the type of protein. External factors include the type of equipment used, and the speed of stirring. Until now, there has not been established any standard methods for measuring the properties of these emulsifiers, therefore, the observations of the various laboratories vary widely with each other and can not be compared (Damodaran, 1996).

The foam power of leucaena concentrates with pressure treatment was $7.55 \%-8.61 \%$. The average foam power of leucaena concentrates with a treatment time of separation was $7 \%-9 \%$ (Table 2 ). The ability of the protein to form a stable foam are indispensable in the production of various foods, such as ice cream, cake, bread, whipped cream and mousse. Protein concentrates is often used in products creamer, milkshake, meat analogues, and so on. Foam is a dispersed structure that combines two colloidal liquids, such as a protein solution and gas dispersing medium as a dispersed phase. The nature of the formation of foam is a protein in which the surface properties of the surface properties is influenced by surface tension. Foam formation associated with reduced surface tension at the air-water system due to the adsorption of protein molecules (Okezie and Bello, 1988). Foam power increases as concentrations of protein increases due to an increase in the thickness of the interfacial layer, the foam stability is obtained when the maximum elasticity of the surface is also maximum. The capacity and stability of the foam is better done at high concentrations because of the increased viscosity of the protein and facilitates the formation of multilayer film that is cohesive and the interfacial surface (Damodaran, 1996).
The previous research has produced leucaena seed protein concentrate that had functional properties of oil absorption capacity of $3.42 \mathrm{~mL} / \mathrm{g}$, the bulk density 0.56 $\mathrm{g} / \mathrm{mL}$, power emulsion $52.75 \%, 6.39 \%$ moisture content on the concentration of enzyme treatment of sheep rumen fluid $(10 \mathrm{~mL} / 100 \mathrm{~g})$ and incubation time of $48 \mathrm{~h}$ (Dedin F.Rosida et al., 2015).

\section{CONCLUSION}

Preparation of leucaena protein concentrates used ultrafiltration membrane of 0:45 $\mu \mathrm{m}$ and obtained greater pressure and longer time to produce to increase in protein content, water absorption, power and emulsion foam power. The optimal functional properties of leucaena protein concentrates was produced at $3.66 \mathrm{~atm}$ pressure and within 45 minutes found the ability of the foam by $9.8 \%, 51.11 \%$ emulsion power, water absorption $3.3 \mathrm{~g}$ water $/ \mathrm{g}$ solid, $1.43 \%$ oil absorption and bulk density $0.59 \mathrm{~g} \mathrm{~mL}$

\section{REFERENCES}

Adebowale K.O and Lawal O.S. 2003. foaming, gelation and Electrophoretic Characteristics of Mucuna Bean (Mucuna pruriens) Protein Concentrates. Journal of Food Chem. 83: 237-246.

Budijanto S, Sitanggang AB and Murdiati W. 2011. Characteristic physico chemical properties and functional winged seed protein isolate (Psophacarpus tetragonolobus L). Journal of Food Technology and Industry. XXII. (2): 130-136

Damodaran S. 1996. Amino Acids, Peptides, and Proteins. Inside: Fennema, O. R (Ed). 1996. Food Chemistry. New York: Marcel Dekker Inc.

Dedin F. Rosida, Constantia F. 2012. The Study on role of red rice in (soybean-Leucaena leuococephala) Tempe Quality. Journal of Rekapangan ISSN 19784163. Vol. 6 No. 1 : 64-72

Dedin F. Rosida, Yulistiani R, Ardiani W, Dedid Cahya Happyanto. 2015. Production of leucaena seed protein concentrate by using hydrolase enzymes from the rumen of sheep. Wulfenia Journal. Vol.22.issue.9 (September 2015): 190-204

Eden J.M., Widmann M., Grawe D, Rast S. 2012. Skill, Correction, and Downscaling of GCM-Simulated Precipitation. American Meteorological Society. AMS Journals online. Volume 25, Issue 11 (June 2012) 
Fardiaz D., Andarwulan N., Wijaya H and Puspitasari N. L. 1992. Technical Analysis and Chemical Properties of Functional Food Components. PAU Food and Nutrition, IPB, Bogor.

Gutman R. G. 1987. Membrane Filtration. The rheological of Pressure Driven Crossflow Procces. IOP Publishing Ltd. England.

Hanson L. P. 1974. Vegetables protein processing. London: Hayes Data Corp. Inside: Ogunwolu S.O., Henshaw F.O., Mock H.P., Santros A., Awonorin S.O. 2009. Functional Properties of Protein Concentrates and isolates Produced From Cashew (Anarcaduim occidentale L.) Nut. Journal of Food Sci. 115: 852- 58.

Hapsari A.W. 2009. Study of physicochemical properties, functional protein, and antioxidant capacity in protein concentrate bean sprouts lablab (Lablab Purpureus (L.) Sweet). Thesis. Faculty of Agricultural Technology. Bogor Agricultural Institute.

Kartika Y. D. 2009. Characterization of functional properties winged seed protein concentrate (Psophocarpus tetragonolobus L). Thesis. Faculty of Agricultural Technology. Bogor Agricultural Institute.

Kinsella J. E 1979. Functional properties of soybean protein. Clock. Oil. Chem. Soc. 56: 242-258.

Lin M. Y., Humbert G. S., and Solunski F. W. 1974. Certain functional properties of sunflower meal products. Journal. Food Sci. 39: 368.

Marella C . 2009. Whey protein fractionation using membrane separation technology. dissertation. South Dakota State University, Brookings.

Marella C., Muthukumarappan K and Metzger L. E. 2013. Application of membrane separation technology for developing novel dairy food ingredients. Journal Food Process Technol 2013, 4:9 http://dx.doi.org/10.4172/2157-7110.1000269

Okezie B. O and Bello A. B. 1988. Physicochemical and functional properties of winged bean flour and isolate compared with soy isolate. Journal Food Sci. 53 (2): 450-454.

Osada Y and Nakagawa T. 1992. Membrane Science and Technology. Marcel Dekker, Inc., New York

Peleg M and Bagley E. B. 1983. Physical Properties of Foods. Westport: AVI Publishing Co. Inside: Ogunwolu, SO, FO Henshaw, HP Mock, A. Santros, SO Awonorin. 2009. Functional properties of protein concentrates and isolates produced from cashew (Anarcaduim occidentale, L.) Nut. Journal Food Sci. 115: 852-858.

Sant'Anna Voltaire, Ligia Damasceno Ferreira Marczak, Isabel Cristina Tessar. 2012. Membrane concentration of liquid foods by forward osmosis: Process and quality view. Journal of Food Engineering. Volume 111, Issue 3, August 2012, Pages 483-489

Sathe S.K., Deshpande S.S and Salunkhe D. K. 1982. Fuctional properties of winged bean (Psophocarpus tetragonolobus (L.) DC) Proteins. Journal Food Sci. 47: 503-509.

Solunski F and Fleming S. E. 1977. Chemical functional and nutritional properties of sunflower protein products. Journal Am. Oil Chem. Soc 54: 100105

Suwarno and Maryani. 2003. Potential hyacinth bean (Lablab purpureus (L) Sweet) as raw materials of protein isolates. Thesis. Faculty of Agricultural Technology. Bogor Agricultural Institute.

Suprihatin. 2009. Protein Hydrolysis of Leucaena seeds. Surabaya: UNESA University Press.

Wenten I. G., 1999. Industrial Membrane Technology. Department of Chemical Engineering. Industrial Technology Faculty. Bandung Institute of Technology Duo

Widowati S., Susi Wijaya S. K and Yulianti R. 1998. Globulin Fraction and Nature Functional Protein Isolates of Soybean Varieties Ten Indonesia. Food Crops Agricultural Research 17: 52-58

Winata A. Y. 2001. Characterization of wheat breadfruit (Artocarpus altilis) drying drum precooking results. Essay. Faculty of Agriculture, IPB, Bogor.

Wirakartakusumah M.A., Abdullah K and Syarief A. M. 1992. Physical properties of food materials. Bogor: Inter-University Center of Food and Nutrition, Bogor Agricultural University.

Zayas J. F. 1997. Functionality of Proteins in Food. Berlin: Springer-Verlag. 